\title{
Evaluation of granular anaerobic ammonium oxidation process for the disposal of pre-treated swine manure
}

With rising environmental concerns on potable watersafety and eutrophication, increased media attention and tighter environmental regulations, managing animal wastes in an environmentally responsible and economically feasible way can be a challenge. In this study, the possibility of using granular anammox process for ammonia removal from swine waste treatment water was investigated. A rapid decrease of $\mathrm{NO}_{2}{ }^{-} \mathrm{N}$ and $\mathrm{NH}_{4}{ }^{+}-\mathrm{N}$ was observed during incubation with wastewater from an activated sludge deodorization reactor and anaerobic digestion-partial oxidation treatment process treating swine manure and its corresponding control artificial wastewaters. Ammonium removal dropped from $98.0 \pm 0.6 \%$ to $66.9 \pm 2.7 \%$ and nearly absent when the organic load in the feeding increased from 232

$\mathrm{mg} \mathrm{COD} / \mathrm{L}$ to $1160 \mathrm{mg} \mathrm{COD} / \mathrm{L}$ and $2320 \mathrm{mg} \mathrm{COD} / \mathrm{L}$. The presence of organic carbon had limited effect on nitrite and total nitrogen removal. At a COD to $\mathrm{N}$ ratio of $0.9, \mathrm{COD}$ inhibitory organic load threshold concentration was $727 \mathrm{mg}$ COD/L. Mass balance indicated that denitrifiers played an important role in nitrite, nitrate and organic carbon removal. These results demonstrated that anammox system had the potential to effectively treat swine manure that can achieve high nitrogen standards at reduced costs. 


\title{
2 Evaluation of granular anaerobic ammonium oxidation process for 3 the disposal of pre-treated swine manure
}

\author{
Shou-Qing $\mathrm{Ni}^{1}$, Ning Yang
}

Shandong Provincial Key Laboratory of Water Pollution Control and Resource Reuse, School of Environmental Science and Engineering, Shandong University, Jinan 250100, China

\section{1. Introduction}

6 Large concentrated swine feeding operations throughout the world are presently producing a

7 huge amount of manure with abundant nitrogen and phosphorus as well as organic matter (Zhang

8 et al., 2006). Liquid swine manure can provide essential nutrients for plant growth. On the other

9 hand, continuing land application for manure disposal could result in excessive nutrient loss from

10 soil to water, causing eutrophication that deteriorates water quality (Karlen, Cambardella \&

11 Kanwar, 2004). Manure also contributes to the production of greenhouse gas emissions (Thorman

12 et al., 2007). Usually, effluent from anaerobic wastewater treatment processes is characterized by

13 a high concentration of nitrogen and a low concentration of organic matters (i.e., a low $\mathrm{C} / \mathrm{N}$ ratio)

14 (Kataoka et al., 2002). Biological nitrogen removal is achieved mostly by complete oxidation to

11 Corresponding author. Tel.: +86 5318836 5660; fax: +86 53188364513 .

2 E-mail address: sqni@sdu.edu.cn. 
$15 \mathrm{NO}_{3}{ }^{-}$with surplus oxygen and subsequent reduction of $\mathrm{NO}_{3}^{-}$to $\mathrm{N}_{2}$ gas under anoxic conditions at

16 the expense of COD. If the $\mathrm{C} / \mathrm{N}$ ratio in wastewater is low, additional carbon for denitrification is

17 required. Special attention needs to be given to $\mathrm{N}_{2} \mathrm{O}$ gas emissions during biological nitrogen

18 removal process (Hu et al., 2013; Kong et al., 2013). Therefore, there is an urgent call for

19 development of sustainable technologies for removals of $\mathrm{N}$ from swine manure with respect to

20 environmental and agricultural benefits.

21 As an autotrophic and cost-effective process for nitrogen removal, anaerobic ammonium

22 oxidation (anammox) process is an alternative to the traditional biological nitrification-

23 denitrification process (Ni \& Zhang, 2013). The discovery of anammox process brought

24 significant progress to conventional biological nitrogen removal process. Some promising

25 characteristics make anammox process to be an attractive and sustainable option (Abma et al.,

26 2007), such as low excess sludge production, no need for aeration and no addition of

27 biodegradable organic carbon (Ni et al., 2010a). In comparison to nitrification-denitrification

28 process, anammox consumes 100\% less biodegradable organic carbon and at least 50\% less

29 oxygen (Tal, Watts \& Schreier, 2006).

30 A long start-up period is expected in anammox process due to the slow growth rate of

31 anammox bacteria (Strous et al., 1998). Reducing the potential for anammox sludge wash-out

32 from the reactor becomes an effective strategy to shorten the start-up period of anammox process.

33 Thus, different types of reactors have been adopted to meet this goal including continuous stirred-

34 tank reactor, anaerobic biological filtrated reactor, sequencing batch reactor (SBR), up-flow

35 reactor and biofilm reactor (Imajo, Tokutomi \& Furukawa, 2004; Isaka, Sumino \& Tsuneda,

36 2007; Strous et al., 1998; van Dongen, Jetten \& van Loosdrecht, 2001). Faster growth of

37 anammox bacteria was observed in a membrane bioreactor with the doubling time of less than 10

38 days, leading to a purity of $97.6 \%$ (van der Star et al., 2008). The formation of sludge aggregates

39 was reported to keep a large amount of active anammox biomass from washing out of the reactor 
40 (Imajo, Tokutomi \& Furukawa, 2004). Therefore, granulation is a feasible method for anammox

41 enrichment.

42 Only a few studies have investigated the possibility of using the anammox process for

43 ammonia removal from swine waste treatment water (Ahn, Hwang \& Min, 2004; Hwang et al.,

44 2005; Molinuevo et al., 2009; Waki et al., 2007). However, there is still a big gap regarding the

45 performance of anammox granules for the treatment of swine manure. The objective of this study

46 was to develop a potential swine manure treatment process that can achieve high nitrogen

47 standards at reduced costs by investigating the performance of anammox granular process fed

48 with pre-treated swine manure effluent.

49 2. Materials \& methods

50 2.1. Granules cultivation and reactor operation

51 Two lab-scale up-flow anaerobic sludge blanket (UASB) rectors were inoculated with $900 \mathrm{~mL}$

52 anammox granules from a running UASB reactor (Ni et al., 2011). The mixed liquor suspended

53 solid and mixed liquor volatile suspended solid of the seed sludge were $4.24 \mathrm{~g} / \mathrm{L}$ and $3.35 \mathrm{~g} / \mathrm{L}$,

54 respectively. The reactors were running in a continuous mode at a HRT of approximately 1.0

55 days. The effluent was recycled from the bottom of the reactor. One reactor was designated as the

56 control one.

57 The reactors were operated at $35^{\circ} \mathrm{C}$ with a working volume of $3.0 \mathrm{~L}$. Different sizes of gravel

58 were placed in the bottom of the reactors. The $\mathrm{pH}$ in the reactor was controlled approximately 7.5

59 using $\mathrm{CO}_{2}$ purge and the anoxic condition was created via argon gas. Before feeding with swine

60 manure, the reactor was pumped with synthetic wastewater prepared by adding ammonium and

61 nitrite to a mineral medium in the required amounts in the form of $\left(\mathrm{NH}_{4}\right)_{2} \mathrm{SO}_{4}$ and $\mathrm{NaNO}_{2}$. The

62 composition of the mineral medium was (g/L): $\mathrm{KHCO}_{3} 0.5, \mathrm{KH}_{2} \mathrm{PO}_{4} 0.0272, \mathrm{MgSO}_{4} \cdot 7 \mathrm{H}_{2} \mathrm{O} 0.3$,

$63 \mathrm{CaCl}_{2} \cdot 2 \mathrm{H}_{2} \mathrm{O} 0.18$ and $1 \mathrm{~mL}$ trace elements solutions I and II (Ni et al., 2010a). The synthetic

64 wastewater was deoxygenated by flushing with argon gas before feeding to the reactor. 
65 The effluents from an activated sludge deodorization reactor and anaerobic digestion-partial

66 oxidation treatment (AD-PO) process treating swine manure were collected. The effluent from

67 the activated sludge deodorization reactor contained $220 \mathrm{mg} / \mathrm{L} \mathrm{NH}_{4}{ }^{+}-\mathrm{N}, 265 \mathrm{mg} / \mathrm{L} \mathrm{NO}_{2}{ }^{-}-\mathrm{N}, 125$

$68 \mathrm{mg} / \mathrm{L} \mathrm{NO}_{3}{ }^{-}-\mathrm{N}$, and $230 \mathrm{mg} / \mathrm{L} \mathrm{COD}$. The effluent from the AD-PO process contained $610 \mathrm{mg} / \mathrm{L}$

$69 \mathrm{NH}_{4}{ }^{+}-\mathrm{N}, 650 \mathrm{mg} / \mathrm{L} \mathrm{NO}_{2}{ }^{-}-\mathrm{N}, 1350 \mathrm{mg} / \mathrm{L} \mathrm{NO}_{3}{ }^{-}-\mathrm{N}$, and $2320 \mathrm{mg} / \mathrm{L} \mathrm{COD}$. Both reactors were

70 initially fed with synthetic wastewater for 35 days. Then one reactor was fed with the effluent

71 from the activated sludge deodorization reactor without dilution and the other one with the

72 effluent from the AD-PO process, which was done gradually in increments of $10 \%, 20 \%, 50 \%$

73 and $100 \%(\mathrm{v} / \mathrm{v})$.

74 2.2. EPSs extraction and analysis

75 The EPSs in the granules were extracted using cation exchange resin (CER). In general, sludge 76 samples were harvested by centrifugation at $3000 \mathrm{rpm}$ for $15 \mathrm{~min}$ at $4{ }^{\circ} \mathrm{C}$ and then the sludge 77 pellets were re-suspended in phosphate buffer solution $(\mathrm{pH} 7.0)$ and the solution was transferred 78 to an extraction bottles, followed by the CER addition with a dosage of $75 \mathrm{~g} / \mathrm{g}$ suspended solids.

79 These suspensions were stirred at $600 \mathrm{rpm}$ at $4{ }^{\circ} \mathrm{C}$ for 2 hours. After removing the settled CER, 80 the solutions were centrifuged at $8000 \mathrm{rpm}$ for $30 \mathrm{~min}$ to remove remaining sludge components.

81 The supernatants were then filtered through $0.45 \mu \mathrm{m}$ cellulose membranes and used as the EPSs

82 fraction for protein and carbohydrate analyses. The protein content in the EPSs was determined

83 according to the Bradford protein assay with bovine serum albumin as the standard (Bradford,

84 1976). The carbohydrate content in the EPSs was measured using the Anthrone method with

85 glucose as the standard (Gaudy, 1962). The total EPSs content was measured as the sum of these

86 two substances.

87 2.3. DNA extraction and quantitative real-time polymerase chain reaction (PCR) 
88 Total genomic DNA was extracted by the modified $2 \%$ cetyl trimethyl ammonium bromide-

89 based protocol (Allen et al., 2006). Genomic DNA preparation was determined with an ND-1000

90 NanoDrop spectrophotometer (NanoDrop Technologies, Wilmington, DE, USA) and purified

91 DNA samples were stored in sterile deionized water at $-20^{\circ} \mathrm{C}$ until used. Quantitative PCR was

92 then processed based on the description of literature (Ni et al., 2011).

\subsection{Fluorescence in-situ hybridization}

94 Fluorescence in situ hybridizations (FISH) and 4,6-diamidino-2-phenylindole (DAPI) staining

95 were performed according to the procedure described by Amann et al. (1990) and Sun et al.

96 (2009). The 16S rRNA-targeted oligonucleotide probes used in this study were AMX368F

97 (CCTTTCGGGCATTGCGAA) and DEN220 (GGCCGCTCCGTCCGC) for anammox and

98 denitrifying bacteria. Images were acquired using an an epifluorescence microscope (Olympus

99 BX51, Olympus Optical, Tokyo, Japan) together with the standard software package delivered

100 with the instrument (version 4.0). The images were taken by an Olympus U-CMAD 3 camera

101 (Olympus Optical, Tokyo, Japan).

102 2.5. Analysis

103 Ammonia was measured by selective electrode according to the Standard Methods (APHA,

104 AWWA \& WEF, 1998). Nitrite and nitrate concentrations were determined by ion-

105 chromatography (DX 500, Dionex, USA). The measurement of COD was carried out according

106 to the Standard Methods 5220 (APHA, AWWA \& WEF, 1998). The SS and VSS were

107 determined by the weighing method after being dried at $103-105^{\circ} \mathrm{C}$ and burnt to ash at $550{ }^{\circ} \mathrm{C}$

108 (APHA, AWWA \& WEF, 1998). For the electron microscopy observation, samples were fixed

109 with $2 \%$ paraformaldehyde and $2 \%$ glutaraldehyde in $0.1 \mathrm{M}$ cacodylate buffer at $4{ }^{\circ} \mathrm{C}$ for $24 \mathrm{~h}$.

110 Samples were then prepared following the method of Ni et al. (2011). For the transmission

111 electron microscopy (TEM), images were captured using a JEM 2100 200kV scanning and

112 transmission electron microscope (Japan Electron Optic Laboratories, Peabody, MA). For the 
113 scanning electron microscopy (SEM), morphology characteristics of the biomass specimens were

114 observed using a JEOL 5800LV SEM (JEOL, Peabody, MA).

\section{3. Results and Discussion}

\section{3.1. Control reactor performance and characteristics of anammox granules}

117 Feeding with synthetic wastewater, the control experiment was carried out at a HRT of 1.0

118 days and the influent $\mathrm{NH}_{4}^{+}-\mathrm{N}$ to $\mathrm{NO}_{2}^{-}-\mathrm{N}$ ratio was kept at around 1.0. Stable performance was

119 realized in several days after the addition of anammox granules. The reactor was run for 35 days

120 with high substrate removal. The average effluent ammonia and nitrite concentrations were $1.0 \pm$

1210.4 and $0.6 \pm 0.9 \mathrm{mg} \mathrm{N} / \mathrm{L}$, respectively (Figure 1), leading to the ammonia and nitrite removal

122 efficiencies of $98.0 \pm 0.8 \%$ and $98.9 \pm 1.7 \%$. Due to the production of nitrate by anammox

123 process, the total nitrogen (TN) removal efficiency was only $83.6 \pm 1.1 \%$.

124 During the experiment, the granules were sampled for the microscope observation. As shown

125 in Figure 2A, the granules in the reactor were reddish, semitransparent and easy to congregate

126 with each other. Each part of the granules was densely incorporated with others, which favored

127 the granules joining tightly and existing stably. This structure was possibly formed due to the

128 shear forces of the effluent recirculation currents (Ni et al., 2011). Spherical shaped bacteria,

129 which were supposed to be anammox bacteria (Jetten et al., 1999), were observed (Figure 2B).

130 Transmission electron micrograph shows that anammox bacterial cells have an irregular

131 morphology (Figure 2C). In this paper, the cells displayed an identical pattern of organization to

132 other anammox species (Kartal et al., 2008).

133 From the SEM image (Figure 2B), anammox cells were surrounded by bacterial extracellular

134 polymeric substances (EPS). EPS were believed to play a fundamental role during the formation

135 of anammox granules (Ni et al., 2010b). Generally, bacterial EPS, consisting of polysaccharides,

136 proteins, nucleic acids, and lipids, are sticky materials secreted by microorganisms, acting as

137 cementing substances in biofilms and flocs (Characklis \& Marshall, 1990; Frolund et al. 1996). 
138 Proteins and carbohydrates were reported to be the dominant components in the extracted EPS

139 and therefore were usually employed to represent the EPS content. During the experiment, the

140 proteins and carbohydrates contents in the extracted EPSs of the granules were analyzed. The

141 total EPSs content was measured as the sum of these two substances. The proteins and

142 carbohydrates in anammox granules were $56.7 \pm 2.8$ and $65.7 \pm 3.2 \mathrm{mg} / \mathrm{g}$ VSS with a

143 protein/carbohydrate (PN/PS) ratio of approximately 0.9 . The total EPSs contents in anaerobic

144 and aerobic granules were around 60 mg/g VSS (Wu et al., 2009; Zheng \& Yu, 2007),

145 substantially lower than that for the anammox granules (total EPSs content was about $122.4 \mathrm{mg} /$

$146 \mathrm{~g}$ VSS) in this study. The PN/PS ratios were higher than 2.0 for anaerobic, aerobic and nitrifying

147 granules (Martinez et al., 2004; Wu et al., 2009; Zheng\& Yu, 2007), while it was lower than 1.0

148 for denitrifying granules (Bhatti et al., 2001), similar to that of this study. This suggested that

149 proteins might be the key EPS constituents for anaerobic, aerobic, and nitrifying granules, but

150 carbohydrates might play a significant function in the development of denitrifying and anammox

151 granules.

152 Quantitative real-time PCR analysis was used to quantify the microbial community of the

153 granules in the reactor, using the assay based on the 16S rRNA gene-specific set of primers

154 AMX809F/AMX1066R. The data indicated that anammox bacteria comprised about 91\% cells in

155 the microorganisms' community, resulting in high $\mathrm{NH}_{4}{ }^{+}-\mathrm{N}$ and $\mathrm{NO}_{2}^{-}-\mathrm{N}$ removal efficiencies.

156 FISH images also showed that anammox bacteria constituted the majority of cells in the

157 community (Figure 3). As shown in Figure 3, a small amount of denitrifying bacteria was

158 observed to be existed together with anammox microorganisms.

159 3.2. Nitrogen removal from pretreated swine manure

160 After more than a month stable operation, ammonium and nitrite removal rates in both

161 reactors reached over $95 \%$, demonstrating that both anammox granular reactors were ready for 
162 further study. Reactor I was fed with the effluent, which contained $220 \mathrm{mg} / \mathrm{L} \mathrm{NH}_{4}{ }^{+}-\mathrm{N}, 265 \mathrm{mg} / \mathrm{L}$

$163 \mathrm{NO}_{2}^{-}-\mathrm{N}, 125 \mathrm{mg} / \mathrm{L} \mathrm{NO}_{3}{ }^{-} \mathrm{N}$ and $230 \mathrm{mg} / \mathrm{L} \mathrm{COD}$, from the activated sludge deodorization reactor

164 for about 50 days. As shown in Figure 4, during the late 22 days, $\mathrm{NH}_{4}{ }^{+}-\mathrm{N}, \mathrm{NO}_{2}^{-}-\mathrm{N}$, and TN

165 removal rate were $92.2 \pm 1.5 \%, 99.3 \pm 0.9 \%$, and $72.0 \pm 1.4 \%$, respectively. Ammonium and

166 nitrite removal rates were very high, indicating the good activities of anammox microorganisms.

167 Due to the existence of $\mathrm{NO}_{3}{ }^{-}-\mathrm{N}$ in the feeding, the calculated $\mathrm{TN}$ removal rate $\left(\left[\right.\right.$ removed $\mathrm{NH}_{4}{ }^{+}-\mathrm{N}$

$\left.168+\mathrm{NO}_{2}^{-}-\mathrm{N}+\mathrm{NO}_{3}^{-}-\mathrm{N}\right] /\left[\right.$ influent $\left.\mathrm{NH}_{4}{ }^{+}-\mathrm{N}+\mathrm{NO}_{2}^{-}-\mathrm{N}+\mathrm{NO}_{3}^{-}-\mathrm{N}\right]$ ) was only $72.0 \%$. The traditional

169 biological nutrient removal may realize higher TN removal with much higher costs (Kunz et al.,

170 2009). An 8-h per cycle sequencing batch reactor with alternating anaerobic-anoxic-

171 anoxic/anaerobic-anoxic/aerobic conditions realized $95 \%$ of $\mathrm{TN}$ reductions for swine manure

172 treatment (Zhang et al., 2006). Besides anammox bacteria, other species such as denitrifiers may

173 contribute to nitrogen removal from wastewater. Process stoichiometry was calculated to get a

174 deep insight of their relations (Figure 4). The stoichiometry molar ratios of $\mathrm{NO}_{2}^{-}-\mathrm{N}^{-}$to $95 \mathrm{mg}$ COD L_1

175 conversion and $\mathrm{NO}_{3}{ }^{-}-\mathrm{N}$ removal to $\mathrm{NH}_{4}{ }^{+}-\mathrm{N}$ conversion were $1.30 \pm 0.01$ and $0.14 \pm 0.008$. More

176 nitrite was removed and fewer nitrates were produced. This finding indicated that organic matters

177 enhanced the nitrogen removal by favoring the denitrifiers and they consumed the surplus nitrite

178 and produced nitrate (Eq. (1) and (2)) (Ni et al., 2012). Anammox may also contribute to more

179 nitrite removal and less nitrate production. Kartal et al. (2007) indicated that anammox bacteria

180 could be mediating dissimilatory nitrate reduction to ammonium, followed by the anaerobic

181 oxidation of the produced ammonium and nitrite with the overall end-product of dinitrogen gas.

182 Though anammox bacteria were disguised as denitrifiers, its pathway was different from

183 'classical' denitrification pathway, in which $\mathrm{N}_{2}$ is produced via nitrite, nitric oxide and nitrous

184 oxide. In anammox pathway, nitrate was reduced to dinitrogen gas via nitrite and ammonium.

185 This process was relatively slow. The nitrate reduction to nitrite proceeded at a rate of $0.3 \pm 0.02$ 
$186 \mathrm{fmol} / \mathrm{cell} /$ day which was only $10 \%$ of the anammox rate. So the surplus nitrite and produced

187 nitrate were mostly consumed by denitrifiers.

$188 \mathrm{NO}_{3}{ }^{-}+0.29 \mathrm{CH}_{3} \mathrm{CH}_{2} \mathrm{CH}_{2} \mathrm{COOH}+\mathrm{H}_{2} \mathrm{CO}_{3} \rightarrow 0.034 \mathrm{C}_{5} \mathrm{H}_{7} \mathrm{O}_{2} \mathrm{~N}+\mathrm{HCO}_{3}{ }^{-}+1.54 \mathrm{H}_{2} \mathrm{O}+0.986 \mathrm{CO}_{2}+$

$189 \quad 0.483 \mathrm{~N}_{2} \quad(1)$

$190 \mathrm{NO}_{2}{ }^{-}+0.19 \mathrm{CH}_{3} \mathrm{CH}_{2} \mathrm{CH}_{2} \mathrm{COOH}+\mathrm{H}_{2} \mathrm{CO}_{3} \rightarrow 0.037 \mathrm{C}_{5} \mathrm{H}_{7} \mathrm{O}_{2} \mathrm{~N}+\mathrm{HCO}_{3}{ }^{-}+1.14 \mathrm{H}_{2} \mathrm{O}+0.585 \mathrm{CO}_{2}+$

$191 \quad 0.48 \mathrm{~N}_{2} \quad(2)$

192 Reactor II was fed with the effluent, which contained $610 \mathrm{mg} / \mathrm{L} \mathrm{NH}_{4}{ }^{+}-\mathrm{N}, 650 \mathrm{mg} / \mathrm{L} \mathrm{NO}_{2}{ }^{-}-\mathrm{N}$, $1931350 \mathrm{mg} / \mathrm{L} \mathrm{NO}_{3}{ }^{-}-\mathrm{N}$, and $2320 \mathrm{mg} / \mathrm{L} \mathrm{COD}$, from the AD-PO process for about 2 months. The

194 presence of organic matters was found to affect anammox process adversely (van de Graaf et al., 195 1996). Anammox microorganisms could not compete with denitrifiers for nitrite and may result 196 in complete inactivation of anammox activity under high organic matter concentration (Güven et 197 al., 2005; Molinuevo et al., 2009). So the feeding in reactor II was done gradually in increments 198 of $10 \%, 20 \%, 50 \%$ and $100 \%$ (Figure 5). The addition of $10 \%$ of AD-PO effluent (organic load of $199232 \mathrm{mg} \mathrm{COD} / \mathrm{L}$ ) resulted in up to $98.0 \pm 0.6 \%$ of high ammonium removal, compared with 200 ammonium removal for activated sludge deodorization reactor effluent $(92.2 \pm 1.5 \%$, organic 201 load of $230 \mathrm{mg} \mathrm{COD} / \mathrm{L})$. The difference was caused by higher ammonium concentration $(\sim 220$ $202 \mathrm{mg} \mathrm{N} / \mathrm{L}$ ) of activated sludge deodorization reactor effluent than that ( $60 \mathrm{mg} \mathrm{N} / \mathrm{L})$ after AD-PO 203 treatment. As high contents of free ammonia were toxic to anammox process (Waki et al., 2007), 204 pretreatments, for example partial oxidation of ammonia to oxidized nitrogen, may facilitate 205 anammox reaction. Then, the feeding rate was increased gradually to organic loads of 464, 1160, 206 and $2320 \mathrm{mg} \mathrm{COD} / \mathrm{L}$, corresponding to $20 \%, 50 \%$ and $100 \%$ of AD-PO effluent. Ammonium 207 removal rates were $88.0 \pm 1.0 \%$ and $66.9 \pm 2.7 \%$ when 464 and $1160 \mathrm{mg}$ COD/L were pumped 208 into the reactor. When $2320 \mathrm{mg}$ COD/L was added, the ammonium removal was dropped quickly 209 to nearly absent. Similar phenomena were reported in literature. Though high ammonium 210 removal of $92.1 \pm 4.9 \%$ was achieved for $2 \%(\mathrm{v} / \mathrm{v})$ UASB-post-digested pig manure effluent $(95$ 
$211 \mathrm{mg} \mathrm{COD} / \mathrm{L}, 75.6 \mathrm{mg} \mathrm{NH}_{4}{ }^{+}-\mathrm{N}$ ) by using anammox process, ammonium removal fell to $0 \%$ when

$2125 \%$ (v/v) UASB-post-digested effluent was added (237 mg COD/L, $\left.189 \mathrm{mg} \mathrm{NH}_{4}{ }^{+}-\mathrm{N}\right)$ (Molinuevo

213 et al., 2009). If coupled with nitrification process, anammox could treat many types of high

214 strength industrial wastewaters (Daverey et al., 2013; Jenni et al., 2014; Lackner et al., 2014; Li

215 et al., 2014). This study indicated that anammox could also treat swine manure with high organic

216 loading rate.

217 However, nitrite removal was seldom affected by organic loading rate. Most time, over 95\% of 218 nitrite removal was achieved (Figure 5). The calculated TN removal rate was less than 50\% due 219 to high concentration of $\mathrm{NO}_{3}^{-}-\mathrm{N}$ in the feeding. The stoichiometry molar ratios of $\mathrm{NO}_{2}^{-}-\mathrm{N}$ to $220 \mathrm{NH}_{4}{ }^{+}-\mathrm{N}$ conversion were $1.07 \pm 0.01$ and $1.18 \pm 0.01$ when 232 and $464 \mathrm{mg} \mathrm{COD} / \mathrm{L}$ were applied, 221 close to the theoretical value (Strous et al., 1998). And this value increased to $1.58 \pm 0.07$ at 1160 $222 \mathrm{mg} \mathrm{COD} / \mathrm{L}$. When organic load of $2320 \mathrm{mg} \mathrm{COD} / \mathrm{L}$ was achieved, ratios of 3.82-8.39 were 223 obtained and as time went by, this ratio increased up to 44.0. In this case the heterotrophic 224 denitrification was the major reaction involved in ammonium removal (Molinuevo et al., 2009). 225 Results from the mass balance showed that the participation of anammox process in the total 226 ammonium and nitrite removal decreased when high percent of AD-PO effluent was 227 implemented, which was replaced by the denitrification part.

228 The physiological changes of biomass were also observed. When organic load of $2320 \mathrm{mg}$ $229 \mathrm{COD} / \mathrm{L}$ was achieved, the disintegration of biomass was registered. The red granules began to 230 turn black and more aggregated biomass disassembled to small parts. Due to the change of 231 running conditions by the addition of more organic matters, anammox communities decreased 232 and denitrifiers took charge of ammonium removal eventually. In this situation, slowly growing 233 anammox bacteria $(Y=0.066 \pm 0.01)$ are incapable of competing with denitrifiers with higher 234 growth yield $(Y=0.3)$. FISH images also showed that there was a reduction in the number of 
anammox cells when $2320 \mathrm{mg} \mathrm{COD} / \mathrm{L}$ was added in comparison with the abundance of anammox

236 microorganisms at organic load of $232 \mathrm{mg} \mathrm{COD} / \mathrm{L}$.

\section{3.3. Effect of organic matters on anammox performance}

238 Literature review showed that high content of organic matters usually inhibited anammox

239 activity. In this study, at a COD to $\mathrm{N}$ ratio of 0.9 , COD inhibitory organic load threshold

240 concentration was $727 \mathrm{mg} \mathrm{COD} / \mathrm{L}$ (Figure 6). Previously, we found the threshold were $308 \mathrm{mg}$

$241 \mathrm{COD} / \mathrm{L}$ and 3.1 for COD to $\mathrm{N}$ ratio (Ni et al., 2012). Both organic matter concentrations and

242 COD to $\mathrm{N}$ ratios affect the performance of anammox bacteria without a general agreement

243 (Chamchoi, Nitisorvut \& Schmidt, 2008; Molinuevo et al., 2009). Batch tests showed that 25 and

$24450 \mathrm{mM}$ acetate resulted in 70 and $22 \%$ inhibition in anammox process (Dapena-Mora et al.,

245 2007). Güven et al (2005) indicated that even $0.5 \mathrm{mM}$ of methanol resulted in the immediate and

246 complete inactivation of anammox activity. About $300 \mathrm{mg} \mathrm{COD} / \mathrm{L}$ (COD to $\mathrm{N}$ ratio of 2) was

247 found to inactivate or eradicate anammox communities under concurrent operation of anammox

248 and denitrification (Chamchoi, Nitisorvut \& Schmidt, 2008). At a COD to N ratio of 0.5, COD

249 inhibitory organic load threshold concentration (defined when ammonia removal dropped to

$25080 \%$ ) were 142 and $242 \mathrm{mg} / \mathrm{L}$ when treating different wastewaters (Molinuevo et al., 2009). High

251 free ammonia (FA) concentration had negative effect on anammox process (Kim et al. 2009;

252 Waki et al., 2007). Ni and Meng (2011) found that $27 \mathrm{mg} / \mathrm{L}$ FA could cause more than 50\%

253 bacterial activity loss, and as high as 61-63 mg/L FA would totally inhibit granular anammox

254 microorganisms. During this experiment, FA concentration was lower than $5.0 \mathrm{mg} / \mathrm{L}$, much lower

255 than the possible toxic concentration to anammox biomass.

256 To further understand the effect of organic matters on anammox performance, mass balance

257 evaluation of participation of different processes was done as illustrated in Table 1. At low COD

258 to $\mathrm{N}$ ratios, variation of COD to $\mathrm{N}$ ratio had limited effect on anammox performance. At COD to

$259 \mathrm{~N}$ ratio of 0.9 , anammox accounted for $98.9 \%$ nitrite removal, while at COD to $\mathrm{N}$ ratio of 0.4 , 
anammox accounted for $88.5 \%$ nitrite removal (Table 1 ). The difference was mainly caused by

261 influent substrate concentration. Somehow, COD removal in reactor I had higher efficiency, i.e.

262 over 70\%. Less than 50\% COD was removed in reactor II at all conditions. COD removal was

263 resulted from denitrification by the denitrifying communities mainly using nitrite as electron

264 acceptor. Hence the competition for nitrite as electron acceptor between the denitrifying bacteria

265 and the anammox communities existed in the reactors. Nitrite (ammonia) consumption via

266 anammox was 98.9\% (98.0\%) when influent COD and ammonium concentrations were $232 \mathrm{mg} / \mathrm{L}$

267 and $67 \mathrm{mg} \mathrm{N} / \mathrm{L}$, but it decreased sharply to $27.5 \%(<5 \%)$ at $2320 \mathrm{mg} \mathrm{COD} / \mathrm{L}$ and $615 \mathrm{NH}_{4}{ }^{+}-\mathrm{N} / \mathrm{L}$

268 (Table 1), indicating that denitrification prevailed anammox process gradually. Denitrification

269 helped to remove nitrite and nitrate when organic matter was available and will become the

270 dominant route in the reactor in time.

\section{4. Conclusion}

273 Nitrogen removal has become a major focus in swine manure treatment since nitrogen is the

274 nutrient concerning the application amount of the manure produced in accordance with an

275 increasing number of governmental regulations. As a novel, autotrophic and cost-effective

276 alternative to the traditional biological nitrification/denitrification removal process, anammox

277 process was proved to be effective for swine manure nitrogen removal. With increasing organic

278 matters, ammonium removal via anammox decreased and the role of denitrifiers in nitrite, nitrate

279 and COD removal became significant, proved by mass balance. To facilitate anammox

280 performance, effective pre-treatment to reduce influent organic carbon was necessary. The

281 introduction of organic matters favored the growth of denitrifiers. At low COD to $\mathrm{N}$ ratios,

282 variation of COD to $\mathrm{N}$ ratios had limited effect on anammox performance.

\section{Conflict of Interests}

284 The authors declare that there is no conflict of interests. 
286 Abma WR, Schultz CE, Mulder JW, van der Star WR, Strous M, Tokutomi T, van Loosdrecht 287 MC. 2007. Full-scale granular sludge Anammox process. Water Science and Technology $288 \quad 55: 27-33$

289 Ahn YH, Hwang IS, Min KS. 2004. ANAMMOX and partial denitritation in anaerobic nitrogen 290 removal from piggery waste. Water Science and. Technology 49:145-153.

291 Allen GC, Flores-Vergara MA, Krasnyanski S, Kumar S, Thompson WF. 2006. A modified 292 protocol for rapid DNA isolation from plant tissues using cetyltrimethylammonium bromide. $293 \quad$ Nature Protocols 1:2320-2325.

294 Amann RI, Krumholz L, Stahl DA. 1990. Fluorescentoligonucleotide probing of whole cells for 295 determinative, phylogenetic, and environmental-studies in microbiology. Journal of 296 Bacteriology 172:762-770.

297 APHA, AWWA, WEF. 1998. Standard methods for the examinations of water and wastewater, 298 20th edition. Washington, DC: American Public Health Association.

299 Bhatti ZI, Sumida K, Rouse JD, Furukawa K. 2001. Characterization of denitrifying granular 300 sludge treating soft groundwater in an upflow sludge-blanket reactor. Journal of Bioscience $301 \quad$ and Bioengineering 91:373-377.

302 Bradford MM. 1976. Rapid and sensitive method for the quantitation of microgram quantities of 303 protein utilizing the principle of protein-dye binding. Analytical Biochemistry 72:248-254.

304 Chamchoi N, Nitisorvut S, Schmidt JE. 2008. Inactivation of ANAMMOX communities under 305 concurrent operation of anaerobic ammonium oxidation (ANAMMOX) and denitrification. 306 Bioresource Technology 99:3331-3336. 
307 Characklis WG, Marshall KC. 1990. Biofilms: a basis for an interdisciplinary approach. In:

308 Characklis WG, Marshall K C, eds. Biofilms. New York: Wiley-Interscience, 3-15.

309 Dapena-Mora A, Fernandez I, Campos JL, Mosquera-Corral A, Mendez R, Jetten MSM. 2007.

310 Evaluation of activity and inhibition effects on Anammox process by batch tests based on the

311 nitrogen gas production. Enzyme and Microbial Technology 40:859-865.

312 Daverey A, Su SH, Huang YT, Chen SS, Sung S, Lin JG. 2013. Partial nitrification and anammox

313 process: A method for high strength optoelectronic industrial wastewater treatment. Water

$314 \quad$ Research 47:2929-2937.

315 Frolund B, Palmgren R, Keiding K, Nielsen PH. 1996. Extraction of extracellular polymers from 316 activated sludge using a cation exchange resin. Water Research 30:1749-1758.

317 Gaudy AF. 1962. Colorimetric determination of protein and carbohydrate. Industrial Water $318 \quad$ Wastes 7:17-22.

319 Güven D, Dapena A, Kartal B, Schmid MC, Maas B, van de Pas-Schoonen K, Sozen S, Mendez

320 R, Op den Camp HJ, Jetten MS, Strous M, Schmidt I. 2005. Propionate oxidation by and 321 methanol inhibition of anaerobic ammonium-oxidizing bacteria. Applied and Environmental 322 Microbiology 71:1066-1071.

$323 \mathrm{Hu}$ Z, Zhang J, Liang S, Xie H. 2013. Impact of carbon source on nitrous oxide emission from 324 anoxic/oxic biological nitrogen removal process and identification of its emission sources.

325 Environmental Science and Pollution Research 20:1059-1069.

326 Hwang IS, Min KS, Choi E, Yun Z. 2005. Nitrogen removal from piggery waste using the 327 combined SHARON and ANAMMOX process. Water Science and. Technology 52:487-494. 328 Imajo U, Tokutomi T, Furukawa K. 2004. Granulation of Anammox microorganisms in up-flow 329 reactors. Water Science and Technology 49: 155-163, 
330

331

332

333

334

335

336

337

338

339

340

341

342

343

344

345

346

347

348

349

350

351

352

353

354

Isaka K, Sumino T, Tsuneda S. 2007. High nitrogen removal performance at moderately low temperature utilizing anaerobic ammonium oxidation reactions. Journal of Bioscience and Bioengineering 103: 486-490.

Jenni S, Vlaeminck SE, Morgenroth E, Udert KM. 2014. Successful application of nitritation/anammox to wastewater with elevated organic carbon to ammonia ratios. Water Research 49:316-326.

Jetten MSM, Strous M, van de Pas-Schoonen KT, Schalk J, van Dongen UG, van de Graaf AA, Logemann S, Muyzer G, van Loosdrecht MC, Kuenen JG. 1998. The anaerobic oxidation of ammonium. FEMS Microbiology Review 22:421-437.

Karlen DL, Cambardella CA, Kanwar RS. 2004. Challenges of managing liquid swine manure. Applied Engineering in Agriculture 20:693-699.

Kartal B, Kuypers MMM, Lavik G, Schalk J, op den Camp HJM, Jetten MSM, Strous M. 2007. Anammox bacteria disguised as denitrifiers: nitrate reduction to dinitrogen gas via nitrite and ammonium. Environmental Microbiology 9:635-642.

Kartal B, van Niftrik L, Rattray J, van de Vossenberg JL, Schmid MC, Sinninghe Damsté J, Jetten MS, Strous M. 2008. Candidatus 'Brocadia fulgida': an autofluorescent anaerobic ammonium oxidizing bacterium. FEMS Microbiology Ecology 63:46-55.

Kataoka N, Suzuki T, Ishida K, Yamada N, Kurata N, Katayose M, Honda K. 2002. Field test of methane fermentation system for treating swine wastes. Water Science and Technology 45:103-112.

Kim I, Lee HH, Chung YC, Jung JY. 2009. High-strength nitrogenous wastewater treatment in biofilm and granule anammox processes. Water Science and Technology 60:2365-2371.

Kong Q, Liang S, Zhang J, Xie H, Miao M, Tian L. 2013. $\mathrm{N}_{2} \mathrm{O}$ emission in a partial nitrification system: dynamic emission characteristics and the ammonium-oxidizing bacteria community. Bioresource Technology 127:400-406. 
355 Kunz A, Miele M, Steinmetz RLR. 2009. Advanced swine manure treatment and utilization in

356 Brazil. Bioresource Technology 100:5485-5489.

357 Lackner S, Gilbert EM, Vlaeminck SE, Joss A, Horn H, van Loosdrecht MCM. 2014. Full-scale

358 partial nitritation/anammox experiences-An application survey. Water Research 55:292-303.

359 Li H, Zhou S, Ma W, Huang P, Huang G, Qin Y, Xu B, Ouyang H. 2014. Long-term performance

360 and microbial ecology of a two-stage PN-ANAMMOX process treating mature landfill

361 leachate. Bioresource Technology doi: http://dx.doi.org/10.1016/j.biortech.2014.02.054

362 Martinez F, Lema J, Mendez R, Cuervo-Lopez F, Gomez J. 2004. Role of exopolymeric protein

363 on the settleability of nitrifying sludges. Bioresource Technology 94:43-48.

364 Molinuevo B, García MC, Karakashev D, Angelidaki I. 2009. Anammox for ammonia removal

365 from pig manure effluents: effect of organic matter content on process performance.

366 Bioresource Technology 100:2171-2175.

367 Ni SQ, Fessehaie A, Lee PH, Gao BY, Xu X, Sung S. 2010b. Interaction of anammox bacteria

368 and inactive methanogenic granules under high nitrogen selective pressure. Bioresource

369 Technology 101:6910-6915.

370 Ni SQ, Gao BY, Wang CC, Lin JG, Sung S. 2011. Fast start-up, performance and microbial

371 community in a pilot-scale anammox reactor seeded with exotic mature granules. Bioresource

372 Technology 102:2448-2454.

373 Ni SQ, Lee PH, Fessehaie A, Gao BY, Sung S. 2010a. Enrichment and biofilm formation of

374 Anammox bacteria in a non-woven membrane reactor. Bioresource Technology 101:1792-

3751799.

376 Ni SQ, Meng J. 2011. Performance and inhibition recovery of anammox reactors seeded with

377 different types of sludge. Water Science Technology 63:710-718.

378 Ni SQ, Ni J, Hu D, Sung S. 2012. Effect of organic matter on the performance of granular

379 anammox process. Bioresource Technology 110:701-705. 
380

381

382

383

384

385

386

387

388

389

390

391

392

393

394

395

396

397

398

399

400

401

402

403

Ni SQ, Zhang J. 2013. Anaerobic ammonium oxidation: From laboratory to full-scale application. BioMed Research International Article ID 469360, doi:10.1155/2013/469360.

Strous M, Heijnen JJ, Kuenen JG, Jetten MSM. 1998. The sequencing batch reactor as a powerful tool for the study of slowly growing anaerobic ammonium-oxidizing microorganisms. Applied Microbiology and Biotechnology 50:589-596.

Sun WJ, Sierra-Alvarez R, Fernandez N, Sanz JL, Amils R, Legatzki A, Maier RM, Field JA. 2009. Molecular characterization and in situ quantification of anoxic arsenite-oxidizing denitrifying enrichment cultures. FEMS Microbiology Ecology 68:72-85.

Tal JEM, Watts J, Schreier HJ. 2006. Anaerobic ammonium-oxidizing (Anammox) bacteria and associated activity in fixed-film biofilters of a marine recirculating aquaculture system. Applied and Environmental Microbiology 72: 2896-2904.

Thorman RE, Chadwick DR, Harrison R, Boyels LO, Matthews R. 2007. The effect on $\mathrm{N}_{2} \mathrm{O}$ emissions of storage conditions and rapid incorporation of pig and cattle farmyard manure into tillage land. Biosystems Engineering 97:501-511.

Van de Graaf AA, de Bruijn P, Robertson LA, Jetten MSM, Kuenen JG. Autotrophic growth of anaerobic ammonium-oxidizing micro-organisms in a fluidized bed reactor. Microbiology $142: 2187-2196$.

Van der Star WR, Miclea AI, van Dongen UG, Muyzer G, Picioreanu C, van Loosdrecht MC. 2008. The membrane bioreactor: a novel tool to grow anammox bacteria as free cells. Biotechnology and Bioengineering 101:286-294.

Van Dongen U, Jetten MSM, van Loosdrecht MCM. 2001. The SHARON®-Anammox® process for treatment of ammonium rich wastewater. Water Science and Technology 44:153-160.

Waki M, Tokutomi T, Yokoyama H, Tanaka Y. 2007. Nitrogen removal from animal waste treatment water by anammox enrichment. Bioresource Technology 98:2775-2780. 
404 Wu J, Zhou HM, Li HZ, Zhang PC, Jiang J. 2009. Impacts of hydrodynamic shear force on 405 nucleation of flocculent sludge in anaerobic reactor. Water Research 43:3029-3036.

406 Zhang Z, Zhu J, King J, Li W. 2006. A two-step fed SBR for treating swine manure. Process 407 Biochemistry 41:892-900.

408 Zheng YM, Yu HQ. 2007. Determination of the pore size distribution and porosity of aerobic 409 granules using size-exclusion chromatography. Water Research 41:pp. 39-46. 
411 Figure 1: Nitrogen removal performance of control reactor feeding with synthetic wastewater.

412 Figure 2: (A) Image showing the reddish anammox granules in a beaker. (B) Scanning electron

413 micrograph showing anammox bacteria surrounded by bacterial extracellular polymeric

414 substances (bar $=400 \mathrm{~nm}$ ). (C) Transmission electron micrograph showing anammox bacterial

415 cells $($ bar $=500 \mathrm{~nm})$.

416 Figure 3: Identification of microorganisms by hybridizing with different fluorescent-labeled

417 probes. A: Probe AMX368F targeting for all bacteria; B: Probe DEN220 targeting for denitrifying 418 bacteria.

419 Figure 4: $\mathrm{NH}_{4}{ }^{+}-\mathrm{N}, \mathrm{NO}_{2}{ }^{-}-\mathrm{N}$ and $\mathrm{TN}$ removal (left axis) and process stoichiometry (right axis)

420 during implementation of the effluent after activated sludge deodorization reactor.

421 Figure 5: $\mathrm{NH}_{4}{ }^{+}-\mathrm{N}, \mathrm{NO}_{2}^{-}-\mathrm{N}$ and $\mathrm{TN}$ removal (left axis) and process stoichiometry (right axis)

422 during gradual implementation of the effluent after anaerobic digestion-partial oxidation

423 treatment.

424 Figure 6: Effect of organic matter on anammox performance treating pretreated swine manure. 


\section{Figure 1}

Nitrogen removal performance of control reactor

Figure 1: Nitrogen removal performance of control reactor feeding with synthetic wastewater.

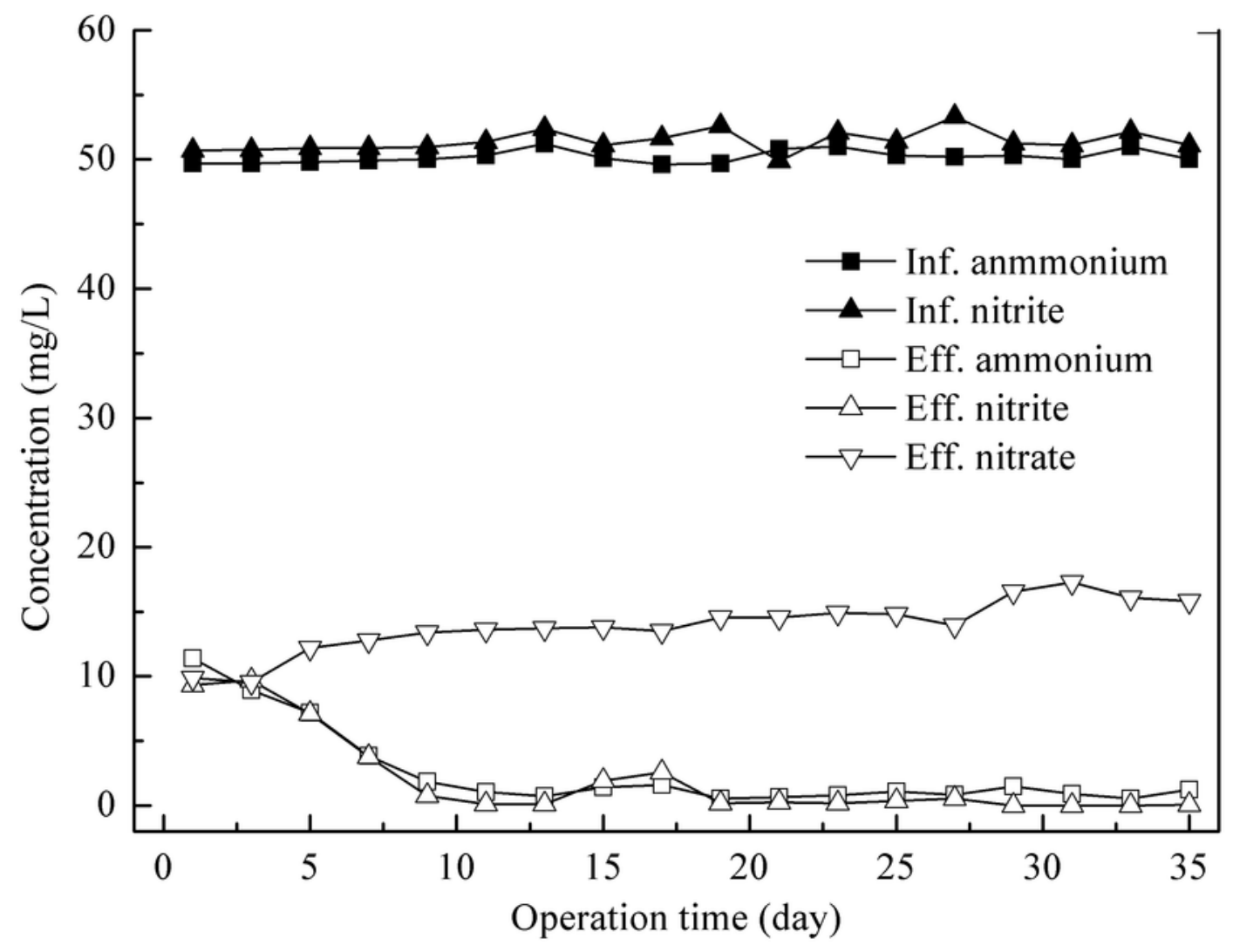




\section{Figure 2}

Images of anammox bacteria

Figure 2: (A) Image showing the reddish anammox granules in a beaker. (B) Scanning electron micrograph showing anammox bacteria surrounded by bacterial extracellular polymeric substances (bar $=400 \mathrm{~nm})$. (C) Transmission electron micrograph showing anammox bacterial cells $($ bar $=500 \mathrm{~nm})$.

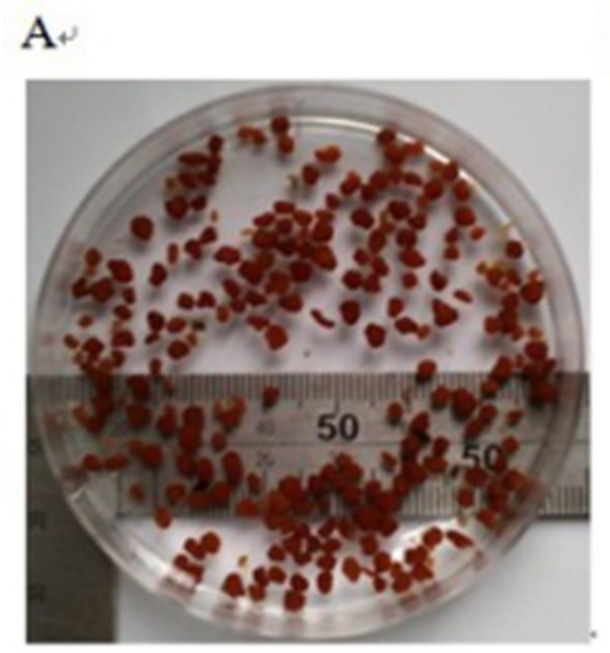

B

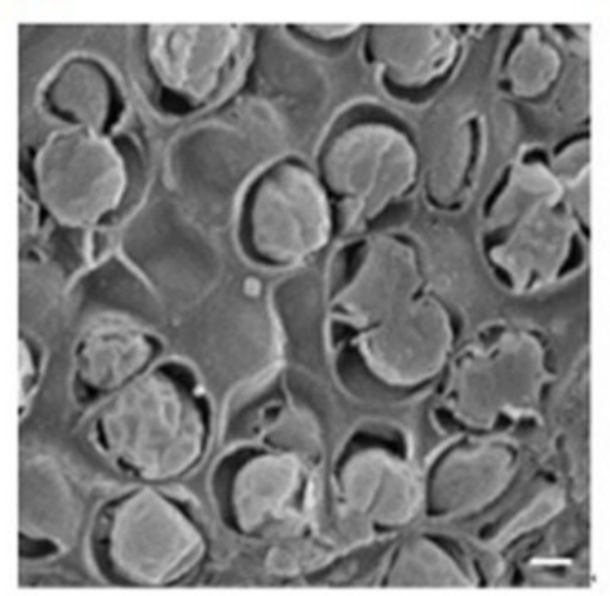

$\mathrm{C}$

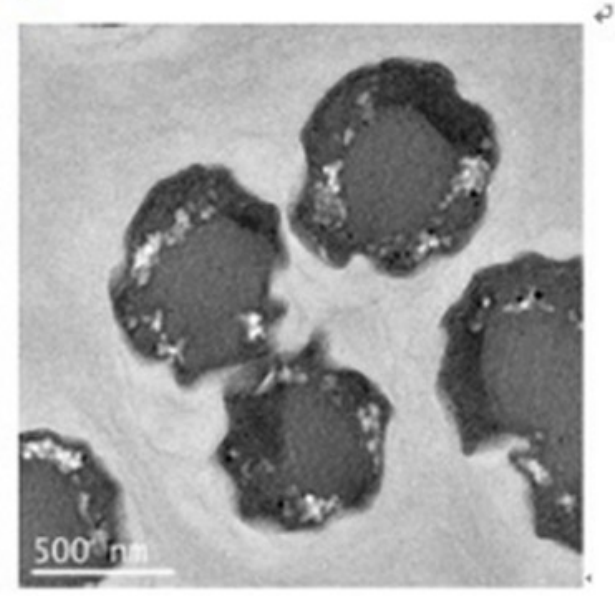




\section{Figure 3}

FISH image

Figure 3: Identification of microorganisms by hybridizing with different fluorescent-labeled probes. A: Probe AMX368F targeting for all bacteria; B: Probe DEN220 targeting for denitrifying bacteria.

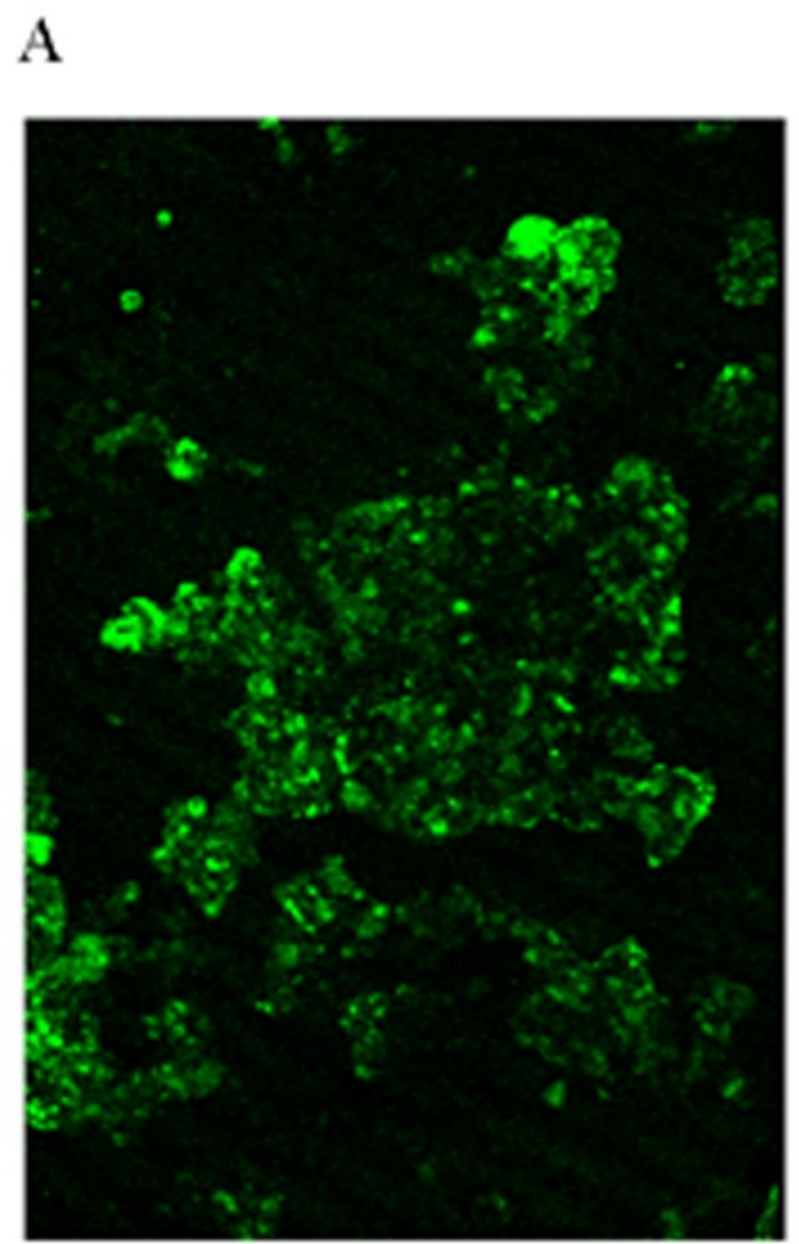

\section{B}

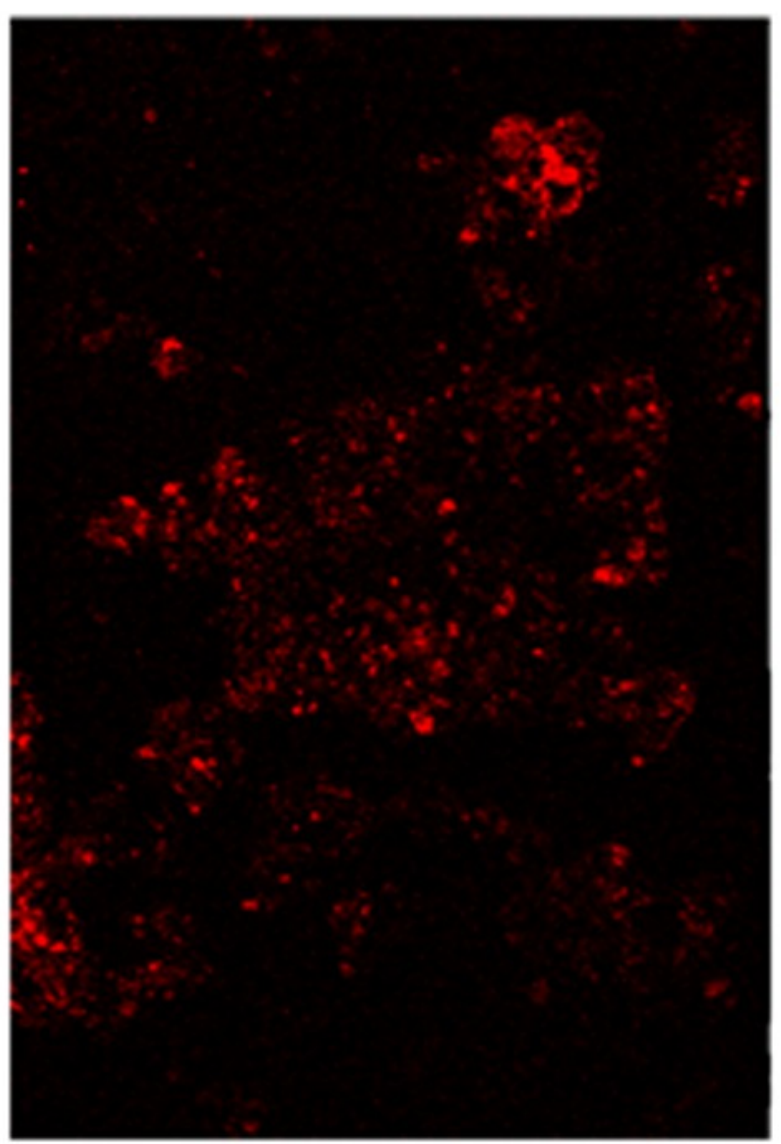




\section{Figure 4}

Treating the effluent after activated sludge deodorization reactor

Figure 4: $\mathrm{NH}_{4}{ }^{+}-\mathrm{N}, \mathrm{NO}_{2}{ }^{-} \mathrm{N}$ and TN removal (left axis) and process stoichiometry (right axis) during implementation of the effluent after activated sludge deodorization reactor.

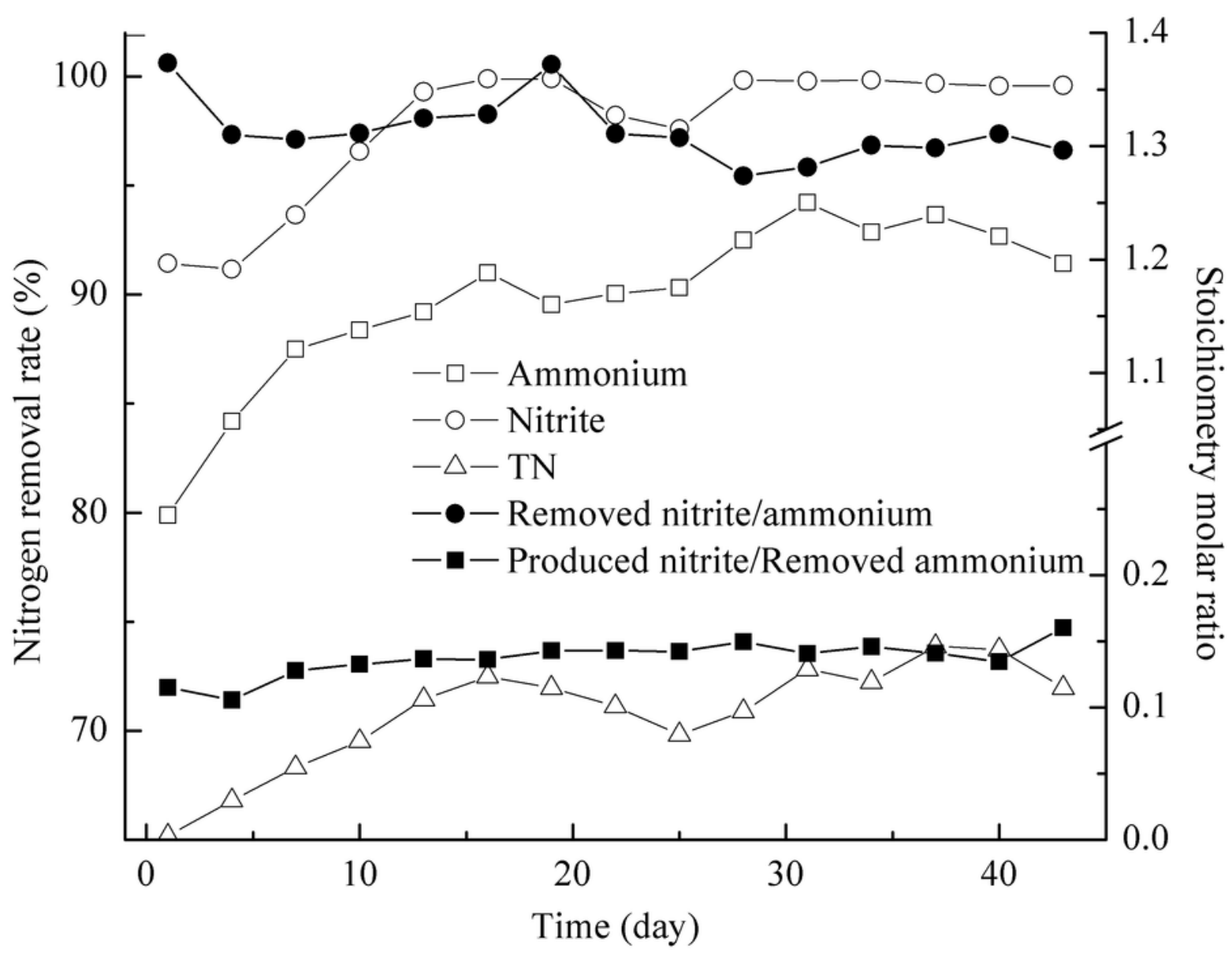




\section{Figure 5}

Treating the effluent after anaerobic digestion-partial oxidation treatment.

Figure 5: $\mathrm{NH}_{4}{ }^{+}-\mathrm{N}, \mathrm{NO}_{2}-\mathrm{N}$ and $\mathrm{TN}$ removal (left axis) and process stoichiometry (right axis) during gradual implementation of the effluent after anaerobic digestion-partial oxidation treatment.

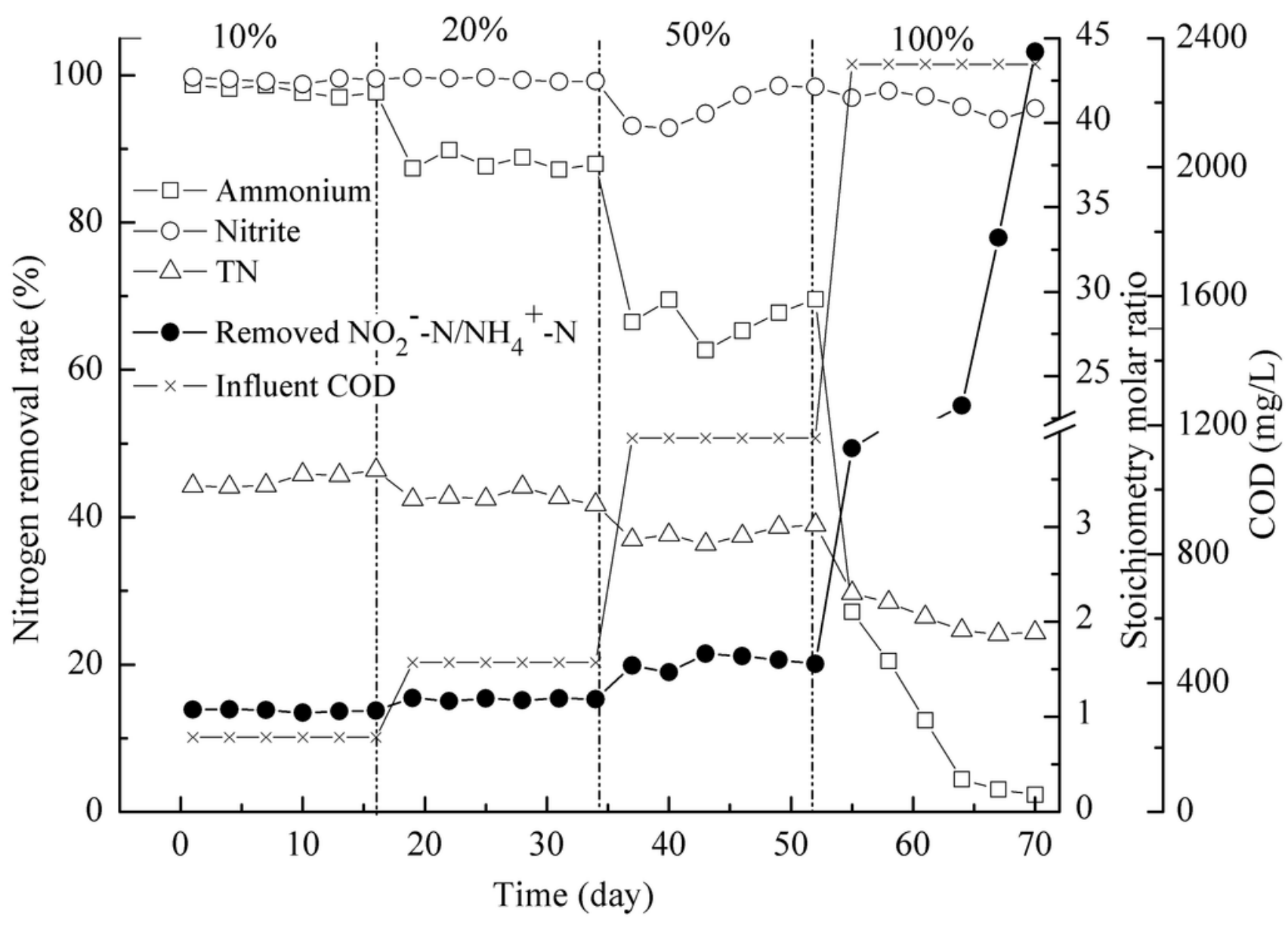




\section{Figure 6}

Effect of organic matter on anammox performance

Figure 6: Effect of organic matter on anammox performance treating pretreated swine manure.

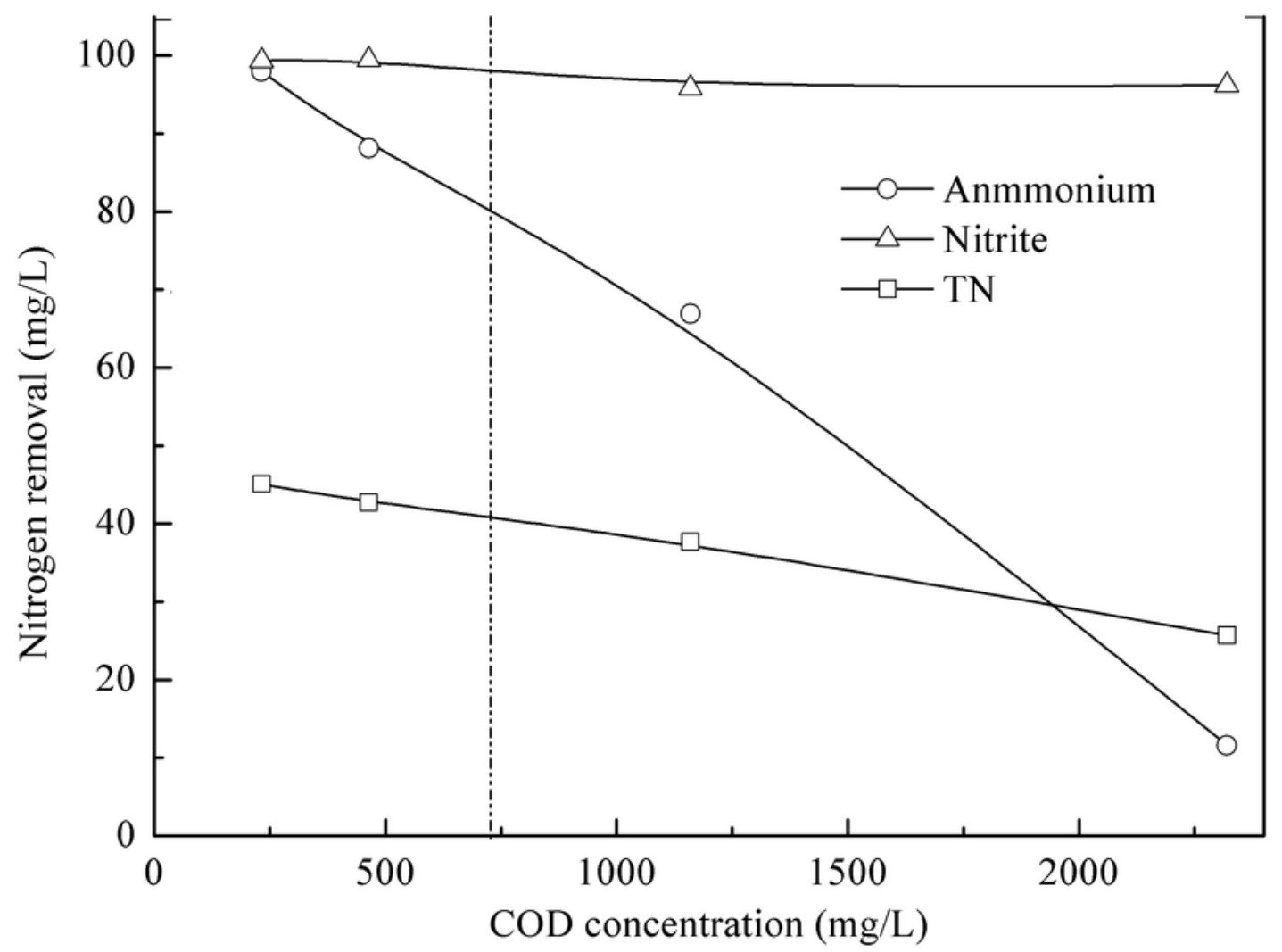




\section{Table 1 (on next page)}

Mass balance

Table 1: Mass balance evaluation of participation of different processes. 
1 Table 1: Mass balance evaluation of participation of different processes.

\begin{tabular}{|c|c|c|c|c|c|c|c|c|c|c|}
\hline \multirow{2}{*}{$\begin{array}{l}\text { COD } \\
\text { conc } \\
\cdot \\
\text { (mg/ } \\
\mathrm{L})\end{array}$} & \multirow{2}{*}{$\begin{array}{l}\mathrm{CO} \\
\mathrm{D} \\
\text { to } \\
\mathrm{N} \\
\text { rati } \\
\mathrm{o}\end{array}$} & \multirow{2}{*}{$\begin{array}{l}\mathrm{NH}_{4}^{+}- \\
\mathrm{N} \\
\text { remo } \\
\text { val } \\
(\mathrm{mg} \\
\mathrm{N} / \mathrm{L}) \\
\end{array}$} & \multicolumn{2}{|c|}{$\begin{array}{c}\mathrm{NO}_{2}-\mathrm{N} \text { removal (mg } \\
\mathrm{N} / \mathrm{L})\end{array}$} & \multicolumn{3}{|c|}{$\mathrm{NO}_{3}^{-}-\mathrm{N}(\mathrm{mg} \mathrm{N} / \mathrm{L})$} & \multirow{2}{*}{$\begin{array}{l}\text { COD } \\
\text { remo } \\
\text { val } \\
(\mathrm{mg} / \\
\mathrm{L})\end{array}$} & \multirow{2}{*}{$\begin{array}{l}\text { Inf. } \\
\mathrm{NH}_{4}^{+}- \\
\mathrm{N}\end{array}$} & \multirow{2}{*}{$\begin{array}{l}\mathrm{NO}_{2}^{-}-\mathrm{N} \\
\text { consump } \\
\text { tion via } \\
\text { anammo } \\
x(\%)\end{array}$} \\
\hline & & & $\begin{array}{l}\text { Anamm } \\
\text { ox }\end{array}$ & $\begin{array}{l}\text { Denitrifica } \\
\text { tion }\end{array}$ & $\begin{array}{l}\text { Product } \\
\text { ion }^{\mathrm{a}}\end{array}$ & $\begin{array}{l}\text { Remo } \\
\text { val }^{\mathrm{b}}\end{array}$ & $\begin{array}{l}\text { Fin } \\
\mathrm{al}^{\mathrm{c}}\end{array}$ & & & \\
\hline $\begin{array}{c}0 \\
232 .\end{array}$ & - & 48.8 & 51.0 & - & 15.8 & - & $\begin{array}{c}15 . \\
8\end{array}$ & - & 50.0 & 100 \\
\hline $\begin{array}{c}0 \\
464 .\end{array}$ & 0.9 & 65.5 & 68.8 & 0.8 & 21.0 & 11.8 & $\begin{array}{l}9.2 \\
21 .\end{array}$ & 41.8 & 67.0 & 98.9 \\
\hline $\begin{array}{c}0 \\
1160\end{array}$ & 0.9 & 115.3 & 121.1 & 15.4 & 37.4 & 15.7 & $\begin{array}{c}7 \\
28 .\end{array}$ & 86.6 & 121.1 & 88.7 \\
\hline $\begin{array}{c}.0 \\
2320\end{array}$ & 0.9 & 211.9 & 222.5 & 107.1 & 68.7 & 40.6 & $\begin{array}{c}1 \\
25 .\end{array}$ & $\begin{array}{l}369.2 \\
1097 .\end{array}$ & 304.5 & 67.5 \\
\hline $\begin{array}{c}.0 \\
230\end{array}$ & 0.9 & 166.9 & 175.2 & 462.6 & 54.1 & 29.0 & $\begin{array}{c}1 \\
35 .\end{array}$ & 6 & 615.0 & 27.5 \\
\hline 0 & 0.4 & 211.2 & 221.8 & 28.9 & 68.4 & 32.5 & 9 & 173.1 & 231.0 & 88.5 \\
\hline
\end{tabular}

$2{ }^{\mathrm{a}}$ Values denote nitrate produced via anammox process.

$3{ }^{\mathrm{b}}$ Values means nitrate removed by denitrification process.

$4 \quad{ }^{c}$ Values stand for final concentration of effluent nitrate. 